\title{
David Oliver: When is it time for older drivers to stop?
}

\author{
David Oliver consultant in geriatrics and acute general medicine
}

Berkshire

On 17 January the Duke of Edinburgh was driving his Land Rover when it was in a collision with another car. One of three passengers in the other car was injured, and the duke's car flipped over. ${ }^{1}$ The duke, 97, was reportedly left bruised and bewildered. Two days later he was seen driving another Land Rover with no seatbelt and was spoken to by police. ${ }^{2}$

As this followed recent stories where drivers over 80 had caused deaths, ${ }^{34}$ it reignited debate. ${ }^{56}$ Driving is a complex skill that can be compromised by a range of medical conditions or changes that get progressively more likely with age. So, when is it time for older drivers to stop driving or be retested? And how should we approach older drivers if we're concerned?

In Great Britain drivers over 70 must renew their licence every three years. ${ }^{7}$ Drivers of all ages must meet the basic legal eyesight requirements and declare any medical conditions or disabilities as required by the Driver and Vehicle Licensing Agency (DVLA). And the DVLA website allows anyone to report concerns about others' fitness to drive on medical grounds. ${ }^{8}$

Doctors must advise patients with a list of specific diagnoses not to drive ${ }^{9}$ and must notify the DVLA directly about drivers who cause them concern. Driving without a licence (including people suspended for medical reasons), or when specifically told by a doctor not to drive for at least three months, is illegal and prosecutable and invalidates insurance. ${ }^{10}$ For greyer areas professionals have good practice guidelines, such as the Royal College of Psychiatrists' Driving with Dementia or Mild Cognitive Impairment. ${ }^{11}$

Taking away an older person's ability to drive is a big step, especially for people with poor access to lifts or public transport

Little of the above is age specific. Legal tests of mental capacity are also age blind, ${ }^{12}$ and the Equality Act 2010 prohibits discrimination by age alone ${ }^{13}$ unless it's a "proportionate means of achieving a legitimate aim." ${ }^{14}$

Taking away an older person's ability to drive is a big step, especially for people with poor access to public transport or lifts from family and friends. Loneliness, social isolation, and the ability to retain independence and connectedness are major factors in wellbeing. ${ }^{15}$ The Royal College of Psychiatrists' guidance contains short, tested questionnaires to prompt older people or their families to consider driving safety, and technology can be installed in cars to help monitor it. ${ }^{16}$

On balance, I'd say that the status quo for older drivers is pragmatic and about right. Of course, we must balance individual drivers' rights against other road users. And it seems reasonable for those involved in crashes to be assessed medically.

But, with over five million UK drivers over $70,{ }^{17}$ formal retesting of them all would be a costly logistical nightmare. And it would single them out for special treatment when, statistically, they're less likely to be involved in serious accidents than younger age groups. ${ }^{18}$

Competing interests: See www.bmj.com/about-bmj/freelance-contributors/davidoliver

Provenance and peer review: Commissioned; not externally peer reviewed.

- bmj.com Observations: Should healthcare professionals breach confidentiality when a patient is unfit to drive? (BMJ 2017;356:j1505, doi:10.1136/bmj.j1505)

Prince Philip: Sandringham crash led to car "tumbling" across road. BBC News 18 Jan 2019. https://www.bbc.co.uk/news/uk-46918039.

2 Police speak to Prince Philip for not wearing seat belt. BBC News 20 Jan 2019. https:// www.bbc.co.uk/news/uk-46935721.

3 Hospital double death crash driver, 90, spared jail. BBC News 7 Nov 2017. https://www. bbc.co.uk/news/uk-england-manchester-41900744.

4 Perring R. M40 crash driver who drove WRONG WAY down motorway was in crash FIVE DAYS EARLIER. Daily Express 18 Oct 2018. https://www.express.co.uk/news/uk/1033344/ m40-crash-wrong-way-Subaru-caravan-video.

5 Older drivers: is age a factor behind the wheel? BBC News 18 Jan 2019. https://www. bbc.co.uk/news/uk-46916429.

6 The elderly and driving: when is it time to hit the brakes? New York Times 18 Jan 2019. https://www.nytimes.com/2019/01/18/health/elderly-driving-cars-safety.html.

7 Driver and Vehicle Licensing Agency. Renew your driving licence if you're 70 or over. https://www.gov.uk/renew-driving-licence-at-70.

8 Driver and Vehicle Licensing Agency. I have concerns over a person's fitness to drive and I wish to tell the DVLA. https://live.email-dvla.service.gov.uk/w2c/en_gb/forms/EFTD\% 20Enquiry?button=none\&decision $=1+$ have + concerns+over $+a+$ person $\%$ $27 \mathrm{~s}+$ fitness+to+drive+and+l+wish+to+tell+the+DVLA\&lang=en gb.

9 Driver and Vehicle Licensing Agency. General information: assessing fitness to drive. 31 Aug 2018. https://www.gov.uk/guidance/general-information-assessing-fitness-to-drive.

10 HM Government. Legal obligations of drivers and riders. https://www.gov.uk/legalobligations-drivers-riders.

11 Royal College of Psychiatrists. Driving with dementia or mild cognitive impairment: consensus guidelines for clinicians. https://www.bgs.org.uk/sites/default/files/content/ resources/files/2019-01-11/Driving\%20with\%20dementia\%20or\%20MCl\%20-\% 20Consensus\%20guidelines\%20for\%20clinicians\%2011.1.19.pdf. 
12 BMA. Mental capacity toolkit. 7 Dec 2018. https://www.bma.org.uk/advice/employment ethics/mental-capacity/mental-capacity-toolkit.

13 Centre for Policy on Ageing. Ageism and age discrimination in health and social care in the UK. 5 Jun 2018. http://www.cpa.org.uk/agediscrimination/age_discrimination.html. 14 HM Government. Equality Act 2010. 8 Apr 2010. https://www.legislation.gov.uk/ukpga/ 2010/15/contents.

15 Age UK. Loneliness research and resources. https://www.ageuk.org.uk/our-impact/policyresearch/loneliness-research-and-resources/.

16 Parkinson C. Hi-tech car aid for older drivers. BBC News 23 Apr 2012. https://www.bbc. co.uk/news/health-17785033.
17 Department for Transport. 30 Nov 2018. https://data.gov.uk/dataset/d0be1ed2-9907-4ec4b552-c048f6aec16a/gb-driving-licence-data.

18 Who, what, why: how dangerous are elderly drivers? BBC News 23 Sep 2013. https:// www.bbc.co.uk/news/magazine-24204489.

Published by the BMJ Publishing Group Limited. For permission to use (where not already granted under a licence) please go to http://group.bmj.com/group/rights-licensing/ permissions 